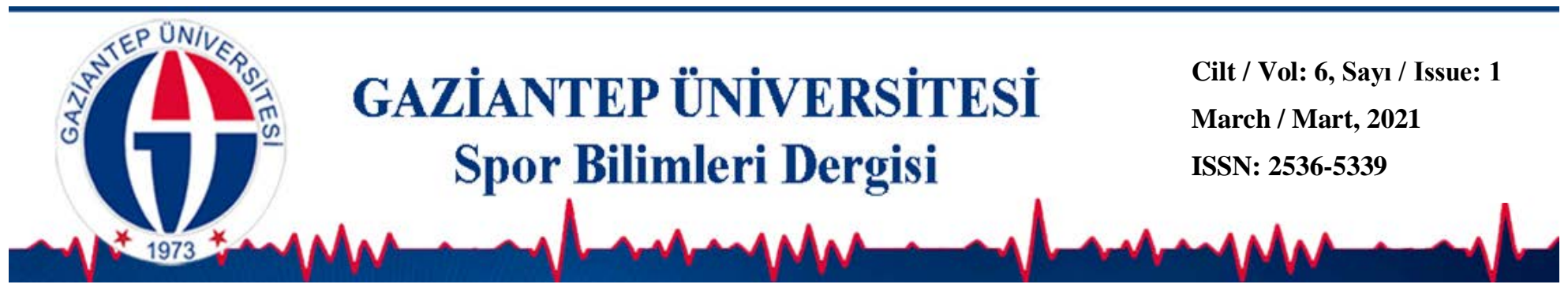

\title{
Domates Suyu Takviyesinin Egzersizde HDL ve LDL Kolesterol Düzeylerine Etkilerinin İncelenmesi
}

\author{
Ragıp PALA ${ }^{* 1}$ (1) Nezihe ŞENGÜN ${ }^{1}$ (1) Leyla Sultan GÜR ${ }^{1}$ (D) Eyyüp YILDIRIM ${ }^{1}$ (D) \\ ${ }^{1}$ Fırat Üniversitesi, Spor Bilimleri Fakültesi, ELAZIĞ
}

DOI: 10.31680/gaunjss.830165

Orijinal Makale / Original Article

Geliş Tarihi / Received: 23.11.2020～Kabul Tarihi / Accepted: 15.02.2021ＹＹayın Tarihi / Published: 22.03.2021

Öz

Sporcularda domates suyu takviyesinin aerobik egzersizde HDL ve LDL kolesterol düzeylerine etkileri incelenmiştir. Bu araştırmaya, yaş ortalaması $20,21 \pm 2,08$ yıl olan, BKI ortalamaları $20,98 \pm 2,61 \mathrm{~kg} / \mathrm{m}^{2}$ olan, farklı branşlarda ortalama $2,50 \pm 1,83$ yıl spor yapan, sağlıklı 14 erkek sporcu katıldı. Sporculara, 21 gün aerobik egzersiz (10 dakika ısınma hareketleri, \%70-80 şiddet aralığında 30 dakika koşu ve 10 dakika soğuma hareketleri) uygulandı ve her egzersiz sonrası $250 \mathrm{ml}$ domates suyu içirildi. 22 ve 42 günler arası arınma dönemine alınarak sadece aerobik egzersiz uygulandı ve $250 \mathrm{ml}$ domates suyu içirilmedi. Veriler, 42 günlük egzersiz öncesi ve egzersiz sonrasında farklılıkları ortaya koymak için SPSS paket programı yardımı ile bağımlı gruplar arası ortalamaların karşılaştırılması için kullanılan testler ile analiz edilmiştir. Verilerin normal dağılıma uygunluğu Shapiro-Wilk testi ile incelenmiştir. Verilerden normal dağılım gösterenler Bağımlı T testi ile normal dağılım göstermeyenler ise Wilcoxon testi ile analiz edilmiştir. İstatistiksel anlamlılık $p<0,05$ olarak kabul edildi. Sporcuların serum HDL düzeylerinde artış olduğu tespit edilmiștir $(p<0,001)$. En yüksek HDL seviyesi egzersiz grubunda görülürken, en düşük HDL seviyesi kontrol gurubunda tespit edilmiştir. LDL düzeyleri egzersiz uygulaması ve egzersiz uygulaması ile birlikte domates suyu verilen sporcuların LDL seviyelerinde istatiksel olarak anlamlı bir düşüş olduğu tespit edilmiştir $(p<0,001)$. Sonuç olarak, aerobik egzersiz uygulanan ve domates suyu takviyesi yapılan sporcularda, serum HDL düzeylerinde artış, LDL düzeylerinde düşüş olduğu tespit edilmiştir. Aerobik egzersiz ile birlikte domates suyu takviyesinin sinerjik bir etki göstererek HDL ve LDL kolesterol düzeylerini regüle ettiği tespit edilmiştir.

Anahtar Kelimeler: Domates suyu, Aerobik egzersiz, HDL, LDL, Kolesterol

\section{Investigation of the Effects of Tomato Juice Supplement on HDL and LDL Cholesterol Levels in Exercise}

\begin{abstract}
The effects of tomato juice supplementation in aerobic exercise on HDL and LDL cholesterol levels were examined in athletes. In this study, 14 healthy male athletes who have been doing sports in different branches for an average of 2.50 \pm 1.83 years and with a mean age of $20.21 \pm 2.08$ years, a mean BMI of $20.98 \pm 2.61 \mathrm{~kg} / \mathrm{m}^{2}$, participated in this study. 21 days of aerobic exercise have been applied to athletes (10 minutes of warm-up, 30 minutes of jogging in the $70-80 \%$ intensity range and 10 minutes of cooling movements) and $250 \mathrm{ml}$ of tomato juice was drunk after each exercise. By taking the washout period between 22 and 42 days, only aerobic exercises were applied and $250 \mathrm{ml}$ of tomato juice was not drunk. The data were analyzed with the SPSS package program to reveal the differences before and after 42 days of exercise, with the tests used to compare the means between dependent groups. The compliance of the data to normal distribution was examined by Shapiro-Wilk test. While Dependent T test were used for analyze the normal distribution data, with those that did not show normal distribution data the Wilcoxon test were used. Statistical significance was accepted as $p<0.05$. It was found that there was an increase in the serum HDL levels of athletes $(p<0.001)$. While the highest HDL level was seen in the exercise group, the lowest HDL level was found in the control group. A statistically significant decrease were determined in the LDL levels of the athletes who were given tomato juice supplementation with exercise and exercise application $(p<0.001)$. As a result, it was determined that there was an increase in serum HDL levels and a decrease in LDL levels in athletes who were applied aerobic exercise and supplemented with tomato juice. It has been found that tomato juice supplementation with aerobic exercise has a synergistic effect and regulates HDL and LDL cholesterol levels.
\end{abstract}

Keywords: Tomato juice, Aerobic exercise, HDL, LDL, Cholesterol

\footnotetext{
* Sorumlu Yazar: Ragip PALA
}

e-mail: rpala23@hotmail.com 


\section{Giriş}

Dislipidemi, serum kolesterol ve düşük yoğunluklu lipoprotein (LDL) kolesterol düzeyinin artması veya yüksek yoğunluklu lipoprotein (HDL) kolesterol düzeyinin azalması olarak tanımlanır. Kolesterol kardiyovasküler hastalıkları belirleyen faktörlerinden biridir (O'Meara, 2004). LDL kolesterol artışı, kandaki trigliserit artışını işaret eder ve bu artış kardiyovasküler hastalık riskini artırır. HDL kolesterol ise damarlardaki fazla kolesterolü karaciğere taşır. Bu görevinden dolayı halk arasında iyi kolesterol olarak adlandırılır. HDL kolestrol seviyesinin yüksek olması, sağlıklı bir kardiyovasküler sistemin bir göstergesidir (Carroll, 2012).

Egzersiz ve sağlıklı beslenme, daha düşük kardiyovasküler hastalık morbidite ve mortalite oranları ile bağımsız olarak ilişkilendirilmiştir (Patnode, 2017). Egzersizin tipine göre kolesterol düzeylerini değiştirebileceğini (Tseng, 2013), düzenli egzersizler LDL kolesterol düzeylerini düşürme, HDL kolesterol düzeylerini artırmanın yollarından biridir (Sarzynski, 2018). Yapılan araştırmalara göre, haftada en az üç ile dört kez en az 20 dakika uygulanan egzersizlerin HDL düzeylerini artırmaya yardımcı olacağını bildirmişlerdir (Kodama, 2007). Domatese kırmızı rengi veren likopen, yağda çözülen güçlü bir antioksidandır ve likopenin LDL'nin oksidatif modifikasyonunu önleyip önleyemeyeceği tartışma konusu edilmiştir. Bugüne kadar, insandaki in vivo çalışmalardan elde edilen sonuçlar tutarlı değildir, bazı çalışmalar diyet likopenin kolesterol düzeylerini engelleyebileceğini bildirirken (Agarwal, 1998), diğer çalışma böyle bir etkinin olmadığını bildirmiştir (Hininger, 2001). Bazı çalışmalar ise güçlü antioksidan özelliklerinden dolayı likopenin lipoprotein metabolizmasını doğrudan etkilediğini öne sürmüşlerdir (Hadley, 2003; Fuhrman, 1997).

Elde edilen literatür bilgilerine göre, bu çalışmada, aerobik egzersiz uygulamaları ve domates suyu takviyesinin HDL ve LDL kolesterol düzeyleri üzerine etkileri incelenmiştir.

\section{Yöntem}

Araştırmada, katılımcılardan bilgilendirilmiş gönüllü olur formu kriter alınarak, yaş ortalaması $20,21 \pm 2,08$ yıl olan, BKi ortalamaları $20,98 \pm 2,61$ olan, farklı

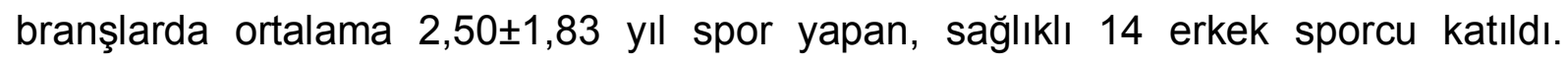
Araştırma ön test ve son test modeline uygun olarak yürütüldü. Araştırma, Fırat Üniversitesi Spor Bilimleri Fakültesine bağlı saha ve tesislerde, mevcut araç ve 
gereçler kullanıldı. Çalışmanın yapılabilmesi için Fırat Üniversitesi Girişimsel Olmayan Araştırmalar Etik Komisyonundan gerekli izin alınmıştır.

\section{Fiziksel Ölçümler}

Boy ölçümü, holtain Itd marka boy ölçer ile alındı. Vücut Ağırlığı Ölçümü, tanita marka baskül ile belirlendi. BKi: Deneklerin kilo değerleri, boy değerlerinin karesine bölünerek (kilo/boy $\mathrm{m}^{2}$ ) hesaplanmıştır.

\section{Egzersiz Uygulaması}

Aerobik egzersiz, 42 gün uygulandı. 14 erkek sporculara, 21 gün aerobik egzersiz uygulandı ve her egzersiz sonrası $250 \mathrm{ml}$ domates suyu içirildi. 22 ve 42 günler arası arınma döneminde aerobik egzersiz uygulandı, $250 \mathrm{ml}$ domates suyu içirilmedi. Aerobik egzersiz, 10 dakika ısınma hareketleri, karvonen formülü kullanılarak MaxVo'nin \%70-80 şiddetinde 30 dakika koşu (Voit Epic II Plus koşu bandı) ve 10 dakika soğuma hareketleri şeklinde uygulandı.

Karvonen Formülü: (220-YAŞ-Dinlenik Nabız) x Antrenman Şiddeti + DN = Maksimum Kalp Atım Hızı (Karvonen, 1957).

\section{Domates Suyu Birleşenleri}

$250 \mathrm{ml}$ domates suyunun toplam enerjisi $50 \mathrm{kkal}$ ve toplam likopen içeriği 27,5 mg'dır. Tablo 1'de yer almaktadır.

Tablo 1. Çalışmada kullanılan domates suyu besin değerleri

\begin{tabular}{cc}
\hline Besin & $\mathbf{2 5 0}$ ml Değer \\
\hline Enerji (Kcal) & 51 \\
\hline Yağ $(\mathrm{g})$ & 0,5 \\
\hline Doymuş Yağ $(\mathrm{g})$ & 0,125 \\
\hline Karbonhidrat $(\mathrm{g})$ & 10,5 \\
\hline Şekerler $(\mathrm{g})$ & 7,5 \\
\hline Protein $(\mathrm{g})$ & 1,75 \\
\hline Lif $(\mathrm{g})$ & 0,375 \\
\hline Tuz & 0,875 \\
\hline Sodyum $(\mathrm{mg})$ & 20 \\
\hline Kalsiyum $(\mathrm{mg})$ & 28,75 \\
\hline Potasyum $(\mathrm{mg})$ & 787,5 \\
\hline A vitamini $(\mu \mathrm{g})$ & 57,5 \\
\hline Likopen $(\mathrm{mg})$ & 27,5
\end{tabular}




\section{Kan örnekleri}

Egzersiz öncesi, 21. gün ve 42. gün egzersiz sonrası tetkikler için katılımcıların kanları alındı. 3 mililitre kan jelli biyokimya tüplerine (Standardplus ve MedicalCo., Ltd., Almanya) alınarak soğutmalı santrifüjde (Universal 320R, Hettich, Almanya) $5000 \mathrm{rpm}$ devir $4{ }^{\circ} \mathrm{C}$ 'de 10 dakika santrifüj edilerek serum örneklerini eppendorf tüplerine bırakılarak analiz edilinceye kadar derin dondurucuda (Hettich, Almanya) $-80^{\circ} \mathrm{C}$ 'de muhafaza edildi.

\section{Serum analizleri}

Yüksek yoğunluklu lipoprotein (HDL), düşük yoğunluklu lipoprotein (LDL), düzeyleri otoanlizörde (Samsung Labgeo PT10) analiz edildi.

\section{Verilerin analizi}

Veriler 42 günlük egzersiz öncesi ve egzersizler sonrasında farklılıkları ortaya koymak için SPSS paket programı yardımı ile bağımlı gruplar arası ortalamaların karşılaştırılması için kullanılan testler ile analiz edildi. Verilerin normal dağılıma uygunluğu Shapiro-Wilk testi ile incelendi. Verilerden normal dağılım gösterenler Bağımlı T testi ile normal dağılım göstermeyenler ise Wilcoxon testi ile analiz edildi. İstatistiksel anlamlılık p<0,05 olarak kabul edildi.

\section{Bulgular}

Tablo 2. Sporculara $(n=14)$ ait yaş, spor yaşı, boy, ağılık ve beden kütle indeksleri (BKI)

\begin{tabular}{|c|c|c|c|c|c|}
\hline Parametre & Ortalama & $\begin{array}{l}\text { Standart } \\
\text { Sapma }\end{array}$ & Medyan & En düşük & En yüksek \\
\hline Yaş, yıl & 20,21 & 2,08 & 20,50 & 18,00 & 24,00 \\
\hline Spor Yaşı, yıl & 2,50 & 1,83 & 2,00 & 1,00 & 8,00 \\
\hline Ağırlık, kg & 62,79 & 6,94 & 62,00 & 54,00 & 76,00 \\
\hline Boy, cm & 173,21 & 6,68 & 172,50 & 164,00 & 188,00 \\
\hline BKİ, $\mathrm{kg} / \mathrm{m}^{2}$ & 20,98 & 2,61 & 21,16 & 17,63 & 26,40 \\
\hline
\end{tabular}

Beden Kütle İndeksi (BKi): ağırlık (kg)/ boyun karesi $\left(\mathrm{m}^{2}\right)$

Çalışmaya katılan sporculara ait yaş, spor yaşı, boy, ağırık ve beden kütle indeksleri (BKi) Tablo 1'de sunulmuştur. Çalışmaya katılan sporcuların yaş ve spor yaşları sırasıyla $20,2 \pm 2,1$ ve 2,5 $\pm 1,8$ yıl olarak tespit edildi. Sporcuların ağırlık ve boy değerleri $62,8 \pm 6,9 \mathrm{~kg}$ ve $173,2 \pm 6,7 \mathrm{~cm}$ olarak ölçülürken, beden kütle indeksleri ise 21,0 $\pm 2,6$ olarak hesaplandı (Tablo 2). 
Tablo 3. Sporcuların serum HDL ve LDL değerleri $(n=14)$.

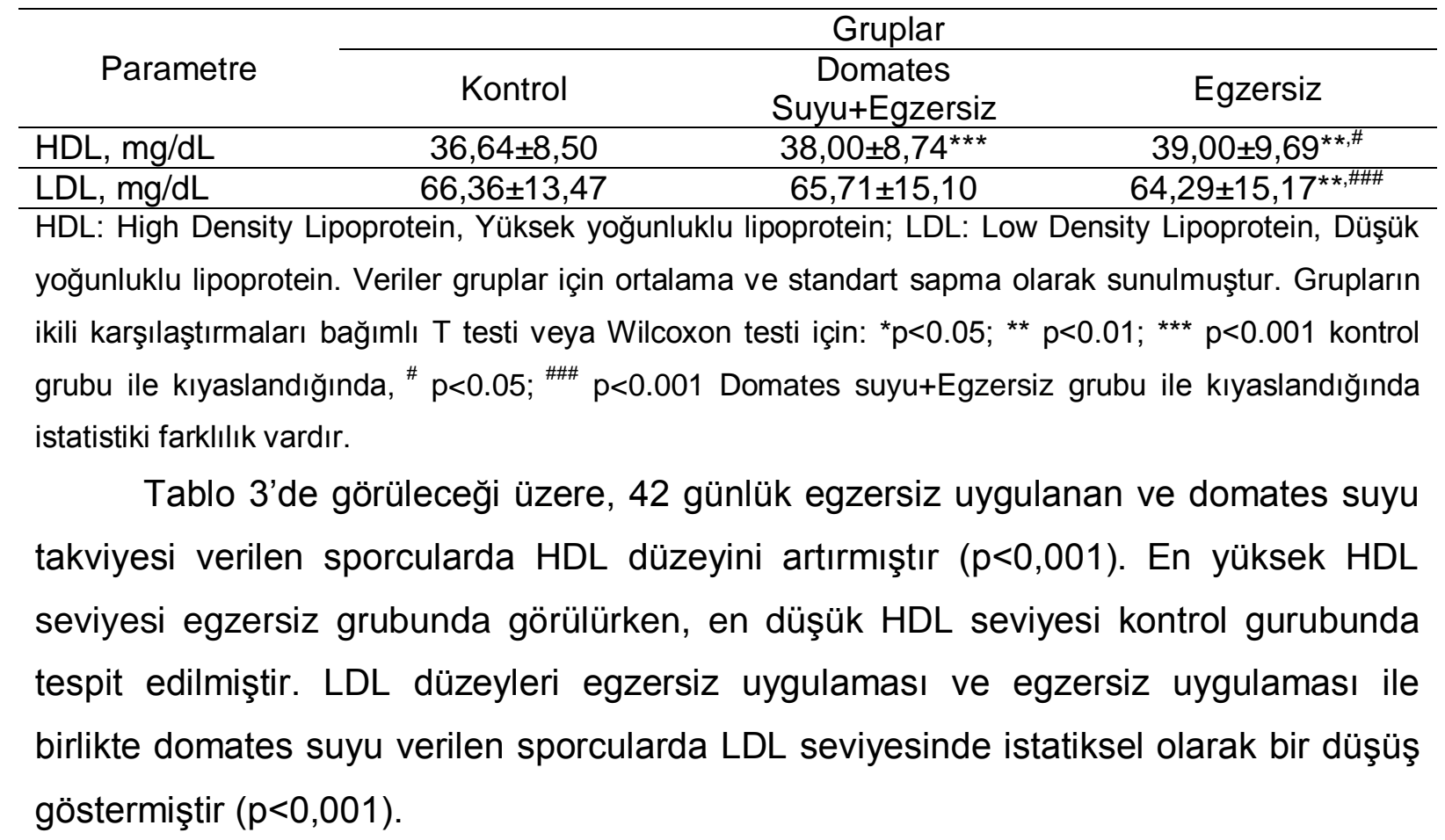

\section{Tartışma ve Sonuç}

$\mathrm{Bu}$ çalışmada, aerobik egzersiz uygulanan sporcularda, domates suyunun HDL ve LDL kolesterol düzeyleri üzerine etkileri incelenmiştir. Egzersiz ve domates suyu takviyesinin sporcularda serum HDL parametresini artırdığı istatistiksel olarak tespit edilmiştir (Tablo 3).

Domates suyu ve egzersiz uygulamasının serum LDL düzeyinde düşüşe neden olduğu tespit edilmiştir (Tablo 3). Bulgularımıza paralel olarak, Ried ve ark., (2011) likopenin kolesterolü ve kan basıncını sağlıklı aralıklarda tutmaya yardımcı olabileceğini bildirmişlerdir. Fuhrman ve ark., (1997) 3 aylık bir süre boyunca 6 erkeğe likopen (60 mg/gün) diyet takviyesinin serum LDL kolesterolde \%14'lük önemli bir düşüş olduğu, Silaste ve ark., (2007) domates suyu takviyesinin LDL kolesterolünde \%17'ye düşürdüğünü bildirilmişlerdir. Odai ve ark., (2019) domates suyu alımının kardiyovasküler risk belirteçleri üzerine yaptıkları çalışmada LDL düzeylerinde önemli ölçüde azalma görüldüğünü bildirmişlerdir. Li ve ark., (2015) vücut kütle indeksleri normal aralıklar içerisinde olan kadınların 2 ay boyunca normal beslenme ve egzersiz programlarına devam ederek günlük $280 \mathrm{ml}$ domates suyu (32,5 mg likopen içeren) takviyesi yapılmış ve domates suyu tüketimi öncesi ve sonrası lipid ve adipokin düzeylerini karşılaştırmışlar, günlük domates suyu takviyesinin, sağlıklı genç kadınlarda serum kolesterol ve inflamatuar adipokin 
düzeylerinin domates suyu takviyesi öncesindeki değerlere göre düşük olduğunu tespit etmişlerdir. Negri ve ark., (2020) çocuklar üzerine yaptıkları çalışmada, domates suyunun HDL düzeyinde artışa yol açtığı, LDL düzeyinde ise düşüşe yol açtığını bildirmişlerdir. Kim ve ark., (2020) erkekler üzerine yaptıkları çalışmada egzersizin HDL kolesterolü artırdığını, LDL kolesterolü düşürdüğünü bildirmişlerdir. Rossi ve ark., (2016) kadınlar üzerine yaptıkları çalışmada, aerobik egzersizin HDL düzeylerinde artış, LDL düzeylerinde azalma olduğunu bildirmişlerdir. Nassef ve ark., (2019) aerobik egzersizin erkek ve kadınlarda HDL kolesterolü artırdığını bildirmişlerdir. Yapılan çalışmalara bakııdığında bulgularımızla paralellik göstermektedir.

Sonuç olarak, aerobik egzersiz uygulanan ve domates suyu verilen sporcularda, serum HDL düzeylerinde artış, LDL düzeylerinde düşüş olduğu tespit edilmiştir. Aerobik egzersiz ve domates suyunun sinerjik bir etki göstererek HDL ve LDL kolesterol düzeylerini regüle ettiği tespit edilmiştir.

\section{Kaynaklar}

Agarwal, S., Rao, A.V. (1998). Tomato lycopene and low density lipoprotein oxidation: a human dietary intervention study. Lipids. 33(10), 981-984.

Carroll, M.D., Kit, B.K., Lacher, D.A. (2012). Total and high-density lipoprotein cholesterol in adults: National Health and Nutrition Examination Survey, 20092010. NCHS Data Brief. 92, 1-8.

Fuhrman, B., Elis, A., Aviram, M. (1997). Hypocholesterolemic effect of lycopene and beta-carotene is related to suppression of cholesterol synthesis and augmentation of LDL receptor activity in macrophages. Biochemical and Biophysical Research Communications. 233, 658-662.

Hadley, C.W., Clinton, S.K., Schwartz, S.J. (2003). The consumption of processed tomato products enhances plasma lycopene concentrations in association with a reduced lipoprotein sensitivity to oxidative damage. J Nutr. 133, 727-732.

Hininger, I.A., Meyer-Wenger, A., Moser, U., Wright, A., Southon, S., Thurnham, D., Roussel, A.M. (2001). No significant effects of lutein, lycopene or $\beta$-carotene supplementation on biological markers of oxidative stress and LDL oxidizability in healthy adult subjects. Journal of the American College of Nutrition. 20(3), 232-238. 
Karvonen, M.J, Kentala, E, Mustala, O. (1957). The effects of training on heart rate: a longitudinal study. Ann Med Exp Biol Fenn. 35(3), 307-15.

Kim, D.J., Kim, J.H. (2020). Effects of Lower Body Muscle Exercise on Blood Lipids and Homocystein. Medico Legal Update. 20(1), 2014-2019.

Kodama, S., Tanaka, S., Saito, K., Shu, M., Sone, Y., Onitake, F., Ohashi, Y. (2007). Effect of aerobic exercise training on serum levels of high-density lipoprotein cholesterol: a meta-analysis. Archives of internal medicine. 167(10), 999-1008.

Li, Y.F., Chang, Y.Y., Huang, H.C., Wu, Y.C., Yang, M.D., Chao, P.M. (2015). Tomato juice supplementation in young women reduces inflammatory adipokine levels independently of body fat reduction. Nutrition (Burbank, Los Angeles County, Calif). 31(5), 691-696.

Nassef, Y., Lee, K.J., Nfor, O.N., Tantoh, D.M., Chou, M.C., Liaw, Y.P. (2019). The impact of aerobic exercise and badminton on HDL cholesterol levels in adult Taiwanese. Nutrients. 11(3), 515.

Negri, R., Trinchese, G., Carbone, F., Caprio, M.G., Stanzione, G., di Scala, C., et al. (2020). Randomised Clinical Trial: Calorie Restriction Regimen with Tomato Juice Supplementation Ameliorates Oxidative Stress and Preserves a Proper Immune Surveillance Modulating Mitochondrial Bioenergetics of T-Lymphocytes in Obese Children Affected by Non-Alcoholic Fatty Liver Disease (NAFLD). Journal of Clinical Medicine. 9(1), 141.

Odai, T., Terauchi, M., Okamoto, D., Hirose, M., Miyasaka, N. (2019). Unsalted tomato juice intake improves blood pressure and serum low-density lipoprotein cholesterol level in local Japanese residents at risk of cardiovascular disease. Food Science Nutrition. 7, 2271-2279.

O'Meara, J.G., Kardia, S.L., Armon, J.J., Brown, C.A., Boerwinkle, E., Turner, S.T. (2004). Ethnic and sex differences in the prevalence, treatment, and control of dyslipidemia among hypertensive adults in the GENOA study. Archives of internal medicine. 164(12), 1313-1318.

Patnode, C.D., Evans, C.V., Senger, C.A., Redmond, N., Lin, J.S. (2017). Behavioral counseling to promote a healthful diet and physical activity for cardiovascular disease prevention in adults without known cardiovascular disease risk factors: updated evidence report and systematic review for the US Preventive Services Task Force. Jama. 318(2), 175-193. 
Ried, K. (2011). Protective effect of lycopene on serum cholesterol and blood pressure: meta-analyses of intervention trials. Maturitas. 68, 299-310.

Rossi, F.E., Fortaleza, A.C., Neves, L.M., Buonani, C., Picolo, M.R., Diniz, T.A., et al. (2016). Combined training (aerobic plus strength) potentiates a reduction in body fat but demonstrates no difference on the lipid profile in postmenopausal women when compared with aerobic training with a similar training load. The Journal of Strength \& Conditioning Research. 30(1), 226-234.

Sarzynski, M.A., Ruiz-Ramie, J.J., Barber, J.L., Slentz, C.A., Apolzan, J.W., McGarrah, R.W., Oda, M.N. (2018). Effects of increasing exercise intensity and dose on multiple measures of HDL (high-density lipoprotein) function. Arteriosclerosis, thrombosis, and vascular biology. 38(4), 943-952.

Silaste, M.L, Alfthan, G, Aro A, Kesäniemi, Y.A, Hörkkö, S. (2007). Tomato juice decreases LDL cholesterol levels and increases LDL resistance to oxidation. British Journal of Nutrition. 98, 1251-1258.

Tseng, M.L., Ho, C.C., Chen, S.C., Huang, Y.C., Lai, C.H., Liaw, Y.P. (2013). A simple method for increasing levels of high-density lipoprotein cholesterol: a pilot study of combination aerobic-and resistance-exercise training. International journal of sport nutrition and exercise metabolism. 23(3), 271-281. 